九州大学学術情報リポジトリ

Kyushu University Institutional Repository

New or Little Known Bees of Japan (Hymenoptera, Apoidea): II. Bees of Colletes and Epeolus of $\mathrm{Ni}$ igata Prefecture with Description of a New Colletes Species

Hirashima, Yoshihiro

Entomological Laboratory, Faculty of Agriculture, Kyushu University

Tadauchi, Osamu

Entomological Laboratory, Faculty of Agriculture, Kyushu University

https://doi.org/10.5109/23701

出版情報：九州大学大学院農学研究院紀要. 24 (2/3)，pp.113-123，1979-11. Kyushu University バージョン：

権利関係 : 


\title{
New or Little Known Bees of Japan (Hymenoptera, Apoidea) \\ II. Bees of Colletes and Epeolus of Niigata Prefecture with Description of a New Colletes Species*
}

\author{
Yoshihiro Hirashima and Osamu Tadauchi \\ Entomological Laboratory, Faculty of Agriculture, \\ Kyushu University 46-01, Fukuoka 812, Japan \\ (Received July 23. 1979)
}

\begin{abstract}
Three species of Colletes (Colletidae) and two species of Epeolus (Anthopholidae) are recorded from Niigata Prefecture for the first time. Cotletes perforator Smith is proposed as a correct name for what was known as Colletes collaris Dours in Japan. Epeolus kimukanus Hirashima is treated as a subspecies of Epeolus tarsalis Morawitz. A new species, Colletes babai, is described.
\end{abstract}

\section{INTRODUCTION}

Recently we received a large collection of bees from Dr. Kintaro Baba which was made by him in Essa Province (Echigo and Sado, Niigata Prefecture). This paper reports the result of our study on his material of two genera, Colletes and Epeolus, only, in addition to a small collection from other source. All of the species reported in this paper are interesting from the view points of taxonomy and distribution of bees.

We are grateful to Dr. Kintaro Baba, a famous amateur entomologist of Japan, for his kind offering of the valuable specimens. We are glad to know that he, as the president of the Essa Konchu Dokokai, is going to celebrate the thirty-third anniversary of its foundation (1946-1979) and the issue of No. 50 of Essa Konchu Dokokai Kaiho.

\section{Genus Colletes Latreille}

Bees of Japanese Colletes have not been studied in detail after Noskiewicz (1936), although Hirashima (1953) described Colletes esakii from the Amami Islands. So far as we know, at least seven species of Colletes occur in Japan including two new species. Among them, a new species is described in this paper. A monographic paper on the Japanese species of Colletes will be published elsewhere (Hirashima and Ikudome, in preparation).

From Essa Province we detected three species. It seems very probable that two more species, C. patellatus Perez and C. vogti Perez, which are not

\footnotetext{
* Contribution from the Entomological Laboratory, Faculty of Agriculture. Kyushu University, Fukuoka (Ser. 3, No. 72).
} 
rare in western Japan, will be found to occur in this region. Therefore a key to these five species of Colletes is given below for the sake of convenience.

Key to the Colletes species of Essa Province

\section{Females}

1. First tergum with broad patches of coarse yellowish hairs on latero-basal portions; 1st tergum smooth, shining and densely punctured ; posterior margin of 1st tergum often broadly ferruginous subhyaline; malar space evident, about one-half as long as basal width of mandible; large species,



- First tergum without such broad patches of coarse yellowish hairs $\cdots \cdots \cdot 2$

2. First tergum smooth, shining, with weak and sparse punctures; hairs on basal portion of 1 st tergum long, soft, white; malar space evident, about one-half as long as basal width of mandible; length about $10 \mathrm{~mm}$............. Colletes sp.

- First tergum densely punctured, although punctures very fine in certain species; malar space shorter, less than one-half of basal width of man-



3. Mesoscutum and scutellum very coarsely and strongly punctured ; punctures on median portion of mesoscutum especially large, irregularly but rather broadly separated from each other; mesoscutum with hairs on median and posterior portions sparse, coarse, fuscous ; length about 10-11 mm

babai, new species

- Mesoscutum and scutellum densely punctured but punctures not especially coarse, densely covered with fulvous hairs, not mixed with darker and coarse ones

4. Larger, length 10-12 $\mathrm{mm}$; punctures on 1st tergum distinct, moderately strong, larger than very weak punctures on 2nd tergum $\cdots \cdot$...patellatus Perez

- Smaller, length about $8 \mathrm{~mm}$; punctures on 1 st tergum very weak, only slightly larger than very fine punctures on 2 nd ….................. vogti Perez

\section{Males}

1. Sixth sternum with a pair of round, deep excavations laterally ; malar space evident, about as long as basal width of mandible... perforator Smith

- Sixth sternum without such round excavations at sides................... 2

2. First tergum smooth, shining, weakly and sparsely punctured; malar space evident, as long as basal width of mandible........ Colletes sp. First tergum very densely punctured; malar space shorter than basal



3. Hind legs modified as follows: femora swollen, tibiae elongate and swollen, basitarsi distinctly expanded, and 2nd tarsal segment shortened; fore and middle legs, especially femora, also slightly swollen $\cdots$ patellatus Perez




4. Malar space distinct, slightly shorter than basal width of mandible; mesoscutum and scutellum strongly punctured, with hairs fulvous, intermixed with brownish ones ..........................................babai, new species

- Malar space short, about one-third as long as basal width of mandible; mesoscutum and scutellum densely covered with pale fulvous hairs, not mixed with darker ones $\ldots \ldots \ldots \ldots \ldots \ldots \ldots \ldots \ldots \ldots \ldots \ldots \ldots$ vogti Pérez

\section{Colletes perforator Smith}

Colletes perforator Smith, 1869, Entomologist, 4 : 205, female (Japan).

Colletes perforator: Cockerell, 1926, Pan-Pacific Ent., 3: 82 (in key).

Colletes perforator: Noskiewicz, 1936, Prace Nauk. Wydawn. Tow. Nank. Lwow II $3: 508$ (citation of the original description).

Colletes collaris: Yasumatsu, 1950, nec Dours, 1872, Icon. Ins. Jap. : 1481 (Japan).

So far as we know, this species has been known as Colletes collayis Dours, 1872 (Rev. mag. 2001. (2) 23: 298) in Japan after the publication of the familiar "Nihon Konchu Daizukan (Iconographia Insectorum Japonicorum)" in 1950. In the summer of 1967, Hirashima examined the type of Colletes perforator Smith at the British Museum (Natural History), London, and confirmed that what is known as Colletes collayis Dours in Japan should be treated as Colletes perforator Smith. The relationship between perforator and collaris is not certain at present, although the latter, which occurs in the Eurasian Continent from Spain to Mongolia and China, is very close to the former so far as the European specimen* is concerned.

Colletes perforator is the largest of Colletes of Japan. The female of this species is easily recognizable by the character of the first metasomal tergum which is densely covered with coarse yellowish hairs on the latero-basal portions. This sort of hair patch is presented only on this species in Japanese Colletes**. This hair patch is not seen in the male, however. The male is also easily separable from other Japanese species in having a pair of deep, round excavations on the 6th sternum at the sides.

Specimen examincd from Essa Province : 1 female, Mt. Awagatake, at about 900 $\mathrm{m}$ above the sea level, M. Echigo, 15. IX. 1969 (K. Baba).

\section{Colletes babai, new species}

Female : Length 10-11 mm.

Integumental color: Black except as follows: apical two-thirds of mandibles reddened ; 3rd-10th flagellar segments beneath broadly brownish ; wings slightly brownish subhyaline; veins and stigma brownish; tegulae reddish brown; legs piceous or deep brownish; tibia1 spurs pale ferruginous; tarsal claws yel-

\footnotetext{
* We examined a female specimen only.

** In Colletes esakii, which is a hairy species like Colletes seitzi Alfken, the first metasomal tergum is densely and broadly covered with coarse hairs basally.
} 


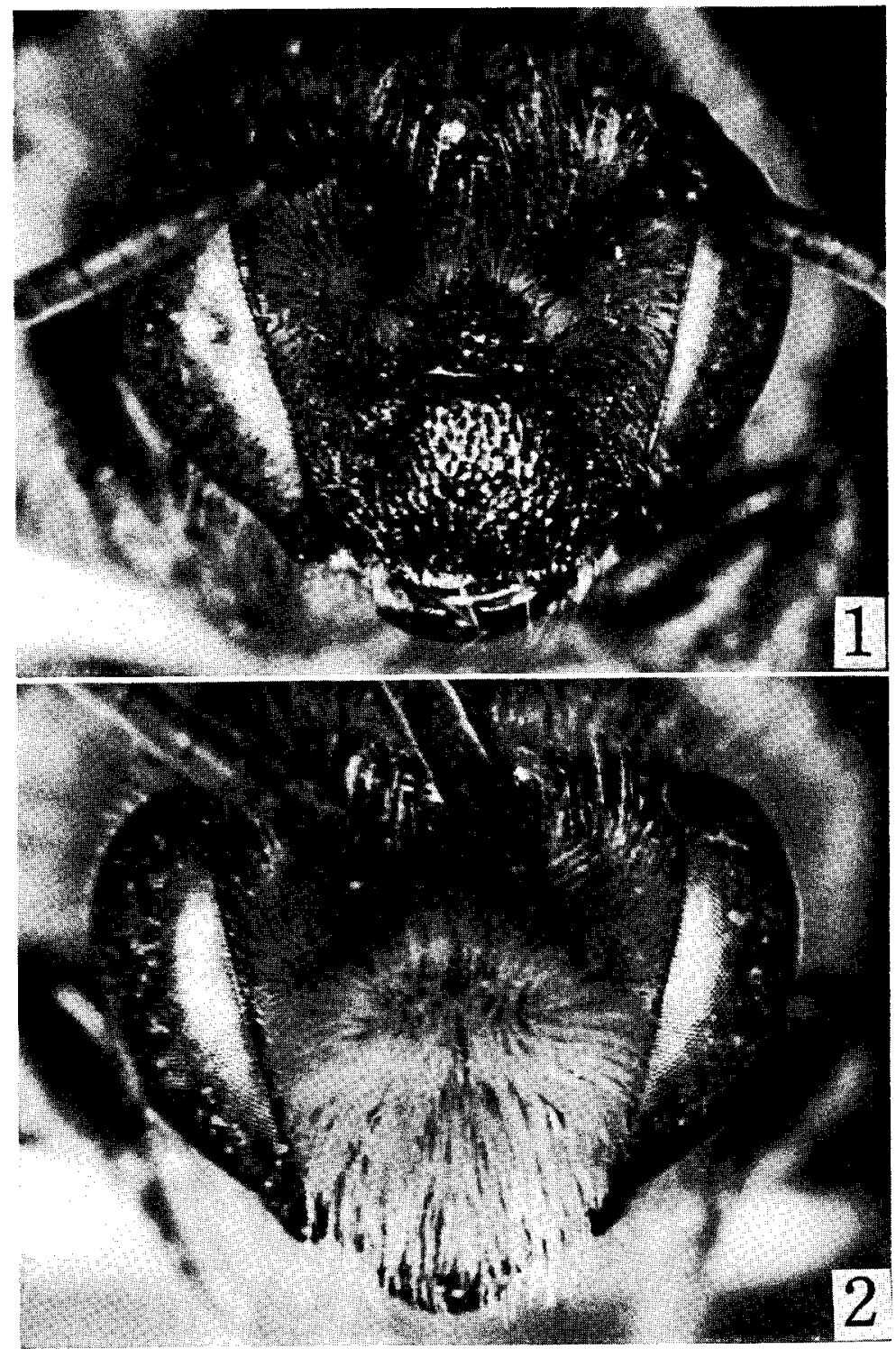

Figs. 1-2. Frontal view of the head of Colletes babai. new species. 1: Female. 2: Male.

lowish basally, reddened apically; posterior margins of metasomal terga and sterna narrowly pale brownish subtransparent (usually covered with dense hairs) ; apical ventrite irregularly reddened.

Pubescence: Hairs on head light fulvous (in fresh specimens), not dense, concentrated chiefly about antenna1 region; hairs on clypeus short, sparse, those on vertex more or less long; hairs on upper genal area not dense, 


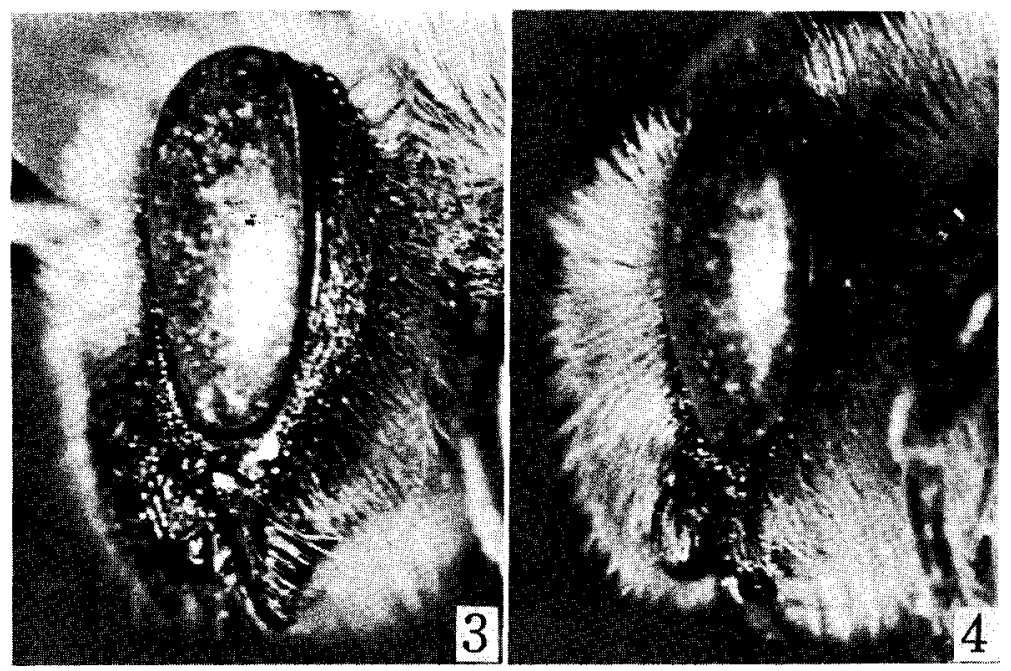

Figs. 3-4. Lateral view of the head of Colletes babai, new species. 3: Female. 4: Male.

short, fulvous, becoming longer towards ventral portion; mesoscutum with short, dense, light fulvous hairs anteriorly, short, sparse, fuscous ones medially and posteriorly, not concealing surface; scutellum with a dense rim of fulvous hairs intermixed with fuscous ones on lateral and posterior edges; mesepisternum with pale fulvous, somewhat long hairs, not concealing surface; dorsal face of propodeum scanty of hairs; upper lateral face of propodeum with dense clumps of short, pale fulvous hairs; lower lateral face of propodeum with very short, sparse, pale fulvous hairs; hairs on hind trochanter long, well curled, rather dense, branched, whitish or slightly yellowish; hairs on hind femur long, dense, curled, well branched, fulvous; 1st metasomal tergum with weak fringes of pale fulvous hairs on lateral edges, weakly extending posteriorly to posterior fringe of 1st tergum; basal margin of 2nd tergum with a transverse band of pale fulvous, appressed hairs; apical margins of Ist-5th metasomal terga with complete bands of appressed pale fulvous hairs, that of 1st sharply, and those of following terga slightly narrowed medially, abruptly narrowed at extreme lateral margins; 2nd-6th terga with short, sparse, brown, suberect hairs, becoming longer towards apical terga; posterior margins of 1st-5th metasomal sterna with weak fringes of sparse, pale fulvous hairs.

Structure: Head nearly as broad as thorax seen from above; clypeus distinctly convex, densely, strongly longitudinally striate-punctate, shiny; apex of clypeus slightly exceeding line running bases of eyes; lower paraocular area rugoso-punctate, punctures much weaker than those on clypeus; supraantennal area coarsely sculptured, flat; facial fovea somewhat shiny, deeply impressed, slightly broadened medially, narrowed below, with upper end occupying nearly one half of distance between orbit and post ocellus, with lower end extending line running upper parts of antennal sockets; vertex shiny with dense, irregular-sized punctures; genal area narrower than eye seen in 
profile, shiny above, weakly shagreened below, with moderately strong punctures; malar space narrow, about one-fourth as long as basal width of mandible; mandibles short, stout; maxillary palpi short, ratio of segments as 0.6 : $0.4: 0.5: 0.4: 0.4: 0.3$; ratio of labial palpal segments as $0.5: 0.4: 0.4: 0.5$; scape longer than 1st-3rd flagellar segments together; 1st flagellar segment longer than broad, longer than 2nd segment which is about as long as broad, longer than 3rd segment which is about as long as or indistinctly longer than broad; eyes with inner margins strongly divergent above; ocelli large, ratio of frontocellar width to postocellar distance to ocelloccipital distance to ocellocular distance to front-postocellar distance as $0.5: 1.0: 0.4: 0.9: 0.4$.

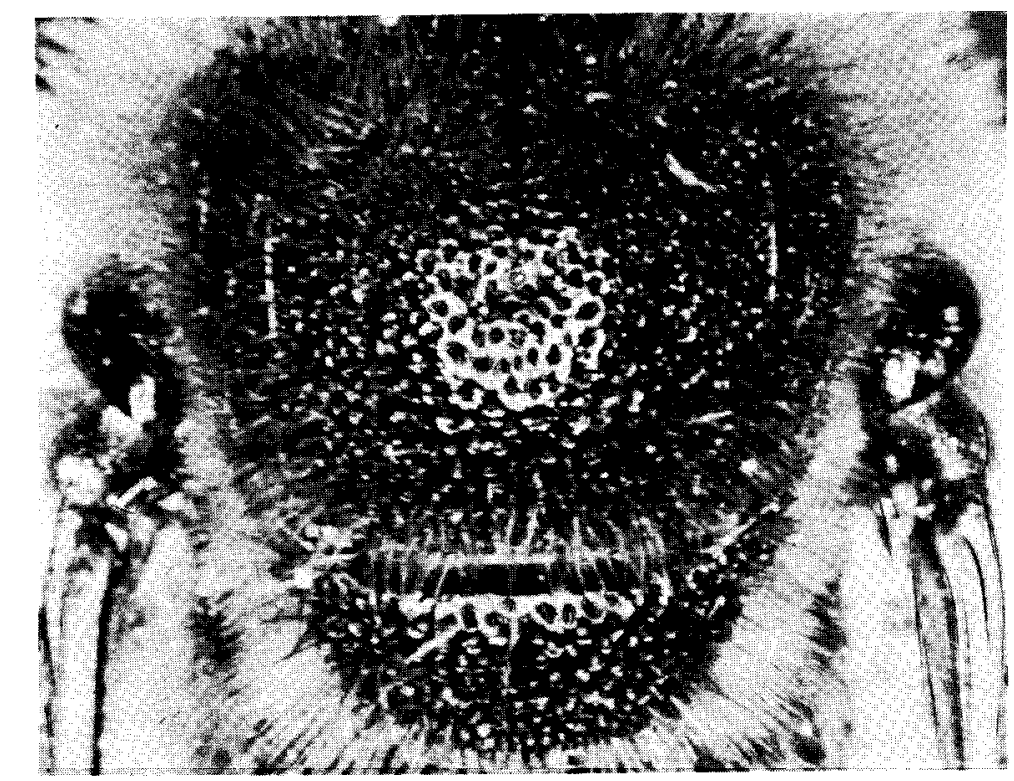

Fig. 5. Dorsal view of the female thorax of Colletes babai, new species, showing the characteristic strong punctation.

Pronotum smooth and shiny, anterior and posterior edges of pronotum raised with shallowly concave disc, most evident at lateral edges; lateral face of pronotum roughened; prothoracic spine evident; pronotal suture weakly indicated, long; mesoscutum smooth and shiny, very coarsely and strongly punctate, punctures smaller and denser anteriorly (except for antero-median portion impunctate) and laterally, lager and sparser medially and posteriorly ; scutellum also coarsely and strongly punctate, shiny anteriorly, weakly tessellate posteriorly; metanotum coarsely sculptured, dull ; mesepisternum rugosopunctate, shiny; metapleural prominence developed above ; propodeal enclosure strongly and longitudinally carinate, nearly foveolate, posterior margin transversely, sharply carinate ; posterior face of enclosure abrupt with moderately strong rugae; dorsal face of propodeum strongly roughened; lateral face of propodeum shagreened with weak rugae; tegulae very weakly tessellate with 
sparse punctures.

Wings with 2nd submarginal cell divergent below, receiving 1st recurrent vein at middle of cell; basal vein distad of nervulus.

Legs with middle basitarsi slightly tapering towards apex, hind basitarsi subparallel-sided ; hind tibiae widened apically.

Metasomal terga smooth and shiny; 1st tergum with dense, distinct punctures which are not specially strong; 2nd-5th terga with finer and denser ones; posterior depressions of terga weakly and narrowly indicated; Ist-5th metasomal sterna weakly tessellate, dull, with small, weak punctures; posterior depressions of sterna more or less well indicated.

Male: Length 8-9 $\mathrm{mm}$.

Integumental color: Black except as follows : mandibles reddened apically ; 2nd-11th flagellar segments broadly brownish below; wings slightly brownish subhyaline; veins and stigma brownish; tegulae deep reddish brown; tarsi reddish brown; tibial spurs pale ferruginous; tarsal claws with basal halves yellowish, apical halves reddened; metasoma with posterior margins of terga and sterna narrowly pale brownish subtransparent (usually covered with hairs).

Pubescence: Hairs on head long, very dense, light fulvous (in fresh specimens), completely concealing clypeus and lower face; hairs on vertex long; upper genal area with short, light fulvous hairs, becoming paler and longer below; head without brownish or fuscous hairs; hairs on thorax moderately long, dense, light fulvous above, paler below, not concealing surface; mesoscutum and scutellum intermixed with sparse brownish hairs; dorsal face of propodeum with moderately long, pale fulvous hairs; upper lateral face of propodeum with dense clumps of not long, pale fulvous hairs; lower lateral face of propodeum with very short, sparse, pale fulvous hairs; legs with sparse, pale fulvous hairs; 1st metasomal tergum with long, erect to suberect, pale hairs; unlike female, lateral fringe of 1st tergum only weakly indicated, pale fulvous; posterior margins of Ist-5th metasomal terga with pale fulvous fringes of dense, appressed hairs, that of 1st sharply, those of following terga slightly narrowed medially; 2nd-6th metasomal terga with suberect, brownish hairs, becoming longer towards posterior terga; 7th tergum with somewhat dense golden hairs; posterior margins of Ist-5th sterna with pale fulvous fringes of dense, subappressed hairs, broadened medially, narrowed laterally.

Structure: Head nearly as broad as thorax seen from above ; clypeus weakly convex, shiny, densely, longitudinally striate-punctate; lower paraocular area shiny, rugoso-punctate ; supra-antennal area coarsely sculptured; facial fovea weakly indicated, shallow, short, weakly shiny; vertex shiny with strong punctures; genal area narrower than eye seen in profile, smooth and shiny near eye, weakly roughened posteriorly; malar space slightly shorter than basal width of mandible; mandibles short, stout; maxillary palpi short, ratio of segments as $0.5: 0.4: 0.5: 0.4: 0.4: 0.5$; ratio of labial palpal segments as $0.6: 0.5: 0.5: 0.5$; scape shorter than 1st and 2nd flagellar segments together; 1st flagellar segment about as long as broad, shorter than 2nd segment which 
is longer than broad; 2nd flagellar segment slightly shorter than 3rd; eyes with inner margins strongly concave above, distinctly converging below ; ocelli large, ratio of frontocellar width to postocellar distance to ocelloccipital distance to ocellocular distance to front-postocellar distance as $0.5: 1$. $0: 0.5: 0.9$ : 0.3 .

Pronotum smooth and shiny, nearly impunctate medially, punctate laterally; lateral edge well indicated; prothoracic spine sharply indicated; pronotal suture weakly indicated; lateral portion of pronotum roughened ; mesoscutum smooth and shiny with dense, strong punctures anteriorly, sparser ones medio-posteriorly; scutellum strongly and irregularly punctate, sparser anteriorly, denser posteriorly ; metanotum coarsely sculptured ; mesepisternum smooth and shiny with very strong punctures ; metapleural prominence developed above ; propodeal enclosure well indicated, defined by a transverse carina posteriorly, interior of enclosure longitudinally carinate; posterior face of enclosure abrupt; dorsal face of propodeum strongly roughened; lateral face of propodeum less sculptured with weak rugae; tegulae nearly smooth with sparse punctures.

Wings as in female.

Legs slender as usual.

Metasomal terga smooth and shiny; 1st tergum with dense, strong, rather coarse punctures, 2nd-6th terga with weaker and smaller, very close punctures ; posterior depressions of terga weakly and narrowly indicated; lst-6th metasomal sterna weakly tessellate, dull, with small, weak punctures; 7th ventral plates rather elongated, moderately widened and truncated at apex, with short, dense, somewhat coarse hairs; each plate with a slight fold on median margin, outer basal corner rounded; basal region with basal articulatory condyle, strongly reflexed with elongate apodeme; 8th sternum subtriangular with moderately long to short, sparse hairs at apex, basal region elongated; genital capsule with dorsal wings of penis valves well developed, ventral wings poorly developed above, widened below; gonostylus with long, dense hairs; penis valves with two volsellae ventro-basally, digitus large, cuspis small.

Distribution : Japan (Hokkaido, Honshu and Kyushu).

Floral record: Not available;

Flight record: Females have been collected from July 9 to September 25 . Males have been collected from July 22 to September 25.

Type material: Holotype female (Type No. 2173, Kyushu Univ.), Kurokawa, N. Echigo (Niigata Pref.), cocoons collected on 15. II. 1958 and emerged in VII. 1958 (K. Baba). Paratypes Honshu: 5 females and 9 males, same data as holotype ; 1 female, same locality and collector as holotype, 9. VII. 1970; 2 females and 3 males, Takane, Asahi-mura, N. Echigo, 25. IX. 1968 (K. Baba) ; 1 male, Mikuni-toge, M. Echigo, 5. VIII. 1963 (H. Itami). Hokkaido: 2 females, Sounkei, Ishikari Prov., 5-6. VIII. 1937 (K. Yasumatsu) : 18 males, Nukabira, Tokachi Prov., 1-4. VIII. 1953 (Y. Hirashima) ; 1 male, Nishiashoro, Tokachi Prov., 6. VIII. 1953 (Y. Hirashima) ; 4 males, Morappu, Lake Shikotsu, Iburi Prov., 11-13. VIII. 1953 (Y. Hirashima) ; 7 males, Higashikawa, Tokachi Prov., 22. VII. 1955 (Y. Hirashima). Kyushu: 1 female, Mt. Hikosan, Buzen, 30. VIII. 
1938 (K. Yasumatsu) ; 1 male, Mt. Kuju, Bungo, 3. VIII. 1940 (T. Esaki) ; 1 male, Mt. Hikosan, Bungo, 22. VIII. 1954 (K. Yasumatsu) ; 1 male, Mt. Hikosan, Buzen, 26. VIII. 1963 (Y. Hirashima).

Type depository: The holotype is preserved in the collection of the Entomological Laboratory, Faculty of Agriculture, Kyushu University.

Remarks: This species is characteristic in having the mesoscutum and scutellum being considerably strongly and coarsely punctate with blackish hairs in the female. This character, however, is not distinctive in the male. This is separable from other Japanese species by the key given above. Outside Japan, this species is similar to Colletes jankowskyi Morawitz from Siberia and Mongolia, but does not accord well with the description of jankowskyi given by Noskiewicz.

\section{Colletes sp.}

This is another new species of Colletes occurring in Japan (Hokkaido and Honshu). The description of this species will be given in a separate paper (Hirashima and Ikudome, in preparation).

The species is characteristic in having the first metasomal tergum smooth, weakly punctured and shining. This is unique for this species. The malar space is also evident in both sexes like Colletes perforator Smith.

Specimen examined from Essa Province: 1 male, Mt. Myoko, S. Echigo, 8. VIII. 1967 (H. Itami).

\section{Genus Epeolus Latreille}

Hirashima (1955) recorded 6 species of Epeolus from Japan and provided a key to them. We were able to examine 5 specimens from Essa Province which represents 2 interesting species.

\section{Epeolus melectiformis Yasumatsu}

Epeolus melectiformis Yasumatsu, 1938, Trans. Sapporo Nat. Hist. Soc., 15: 225, male (type) and female (Ookawamura, Tosa Province).

Epeolus melectiformis: Hirashima, 1955, Ins. Mats., 19(1-2): 42 (in key) ; Hirashima, 1956, Kontŷ̂,24(4); 239 (Hokkaido and Kyushu).

Epeolus melectiformis: van Lith, 1956, Tijd. Ent., 99(1-2) : 39 (redescription).

This interesting species is a close relative of Epeolus tarsalis Morawitz, 1873 (van Lith, 1956). In Japan this species is not common but not extremely rare. The male of this species is easily separable from that of the next species, Epeolus tarsalis himukanus Hirashima, by the presence of long curled fuscous hairs on the 4th and 5th sterna. For further key characters see Hirashima (1955).

This is the first record of this species from Honshu.

Specimens examined from Essa Province : 1 female, Mt. Kinpoku, Sado, 7. VII. 




Figs. 6-7. Frontal view of the male head of Epeolus. 6: melectiformis. 7: tarsalis himukanus.

1936 (K. Baba) ; 2 males, Mt. Madarao, S. Echigo, 26. VIII. 1970 (K. Baba); 1 male, Yuzawa, M. Echigo, 8. VIII. 1966 (H. Itami).

L)istribution: Japan (Hokkaido, Honshu, Shikoku and Kyushu).

Epeolus tarsalis himukdnus Hirashima

Epeolus himukanus Hirashima, 1955, Ins. Mats., 19 (1-2): 40, male (Funaishi- 
Okawachi, Hyuga Province).

Epeolustarsalis subsp. van Lith, 1956, Tijd. Ent., 99(1-2): 35 (Mt. Yufu, Kyushu).

J. P. van Lith (1956) suggested that Epeolus himukanus Hirashima is very likely a subspecies of $E$. tarsalis Morawitz. Upon an examination of the continental specimen of tarsalis we treat here himukanus as a subspecies of tarsalis.

This species is very rare in Japan. The male specimen from Essa Province is the first one to us since the description of himukanus. It is much smaller than the type male. The face of the male is more densely covered with silvery hairs than in melectiformis (Figs. 6 and 7), and the facial process between the antennae is smaller and the frontal carina is weaker than in the latter.

The female of himukanus is still not known.

Specimen examined from Essa Province: 1 male, Fujitsukahama, Shiunji-machi, N. Echigo, 3. X. 1964 (H. Itami).

Distribution : Japan (Honshu and Kyushu).

Flight record: Interestingly, all the three male specimens ever recorded, by Hirashima (1955), van Lith (1956) and the present paper, were collected in the first half of October.

\section{REFERENCES}

Cockerell. T. D. A. 1926 Some bees in the collection of the California Academy of Sciences. Pan-Pacif. Ent., 3(2) : 80-90 (Colletes perforatus (!) Smith in key)

Hirashima, Y. 1955 A new species of the genus Epeolus Latreille from Japan (Hymenoptera: Apidae). Ins. Mats.,19(1-2): 40-43 (Description of E. himukanus and a key to the Japanese species)

Hirashima, Y. 1956 New record of Epeolus melectiformis Yasumatsu from Hokkaido and Shikoku. Kontyâ, 24(4): 239 (In Japanese)

Hirashima, Y. 1958 Bees of the Amami Islands, I (Hymenoptera, Apoidea). Mushi.32(6): 69-76, 2 pls. (Description of Colletes esakii)

Noskiewicz, J. 1936 Die Palearktischen Colletes-Arten. Prace Nauk, Wydawn. Tow. Nauk. Lwow, II 3: 1-532, 28 pls.

van Lith, J. P. 1956 Notes on Epeolus (Hymenoptera Aculeata, Apidae).Tijd. Ent., 99 (12): 31-45 (Note on $E$. himukanus Hirashima and redescription of $E$. melectiformis)

Yasumatsu, K. 1938 Schmuckbienen (Epeolus) der mandschurischen Subregion (Hymenoptera, Apoidea). Trans. Sapporo Nut. Hist. Soc., 15(4): 223-226 (Description of E. melectiformis)

Yasumatsu, K. 1950 Colletes collaris Dours, In "Iconographia Insectorum Japonicorum", ed. by T. Ishii et al., Hokuryukan, Tokyo, p. 1581 (In Japanese) 